\title{
Deuteronomy Reads the Pentateuch
}

\author{
Joel S. Baden \\ Yale University New Haven, CT UsA \\ joel.baden@yale.edu
}

\begin{abstract}
The parallel narratives in Deuteronomy and in Exodus-Numbers have long provided a basis for literary-historical investigations of the composition of the Pentateuch. They also, however, contribute significantly to a canonical reading of Deuteronomy and its place in the Pentateuch. The parallel stories - and specifically the differences between them - allow for a sharper definition of Deuteronomy's message, the character of Moses, and the nature of biblical interpretation.
\end{abstract}

\section{Keywords}

Deuteronomy - Exodus - Numbers - Pentateuch - Moses

Scholarship has devoted much time and effort to determining the genetic literary relationship between Deuteronomy and the parallel narratives in Exodus and Numbers. ${ }^{1}$ These investigations have proven fruitful for discerning the history of the Pentateuch's composition, to be sure, as well as for considering the nature of Israelite scribal culture and for isolating the independent concepts and beliefs inherent in each of the Pentateuch's literary sources and/or layers.

1 See recently, e.g., Eckart Otto, Das Deuteronomium im Pentateuch und Hexateuch (FAT 30; Tübingen: Mohr Siebeck, 200o); John E. Harvey, Retelling the Torah: The Deuteronomistic Historian's Use of Tetrateuchal Narratives (Jsots 43; London: T\&T Clark, 2004), 7-32; Martin Rose, Deuteronomist und Jahwist: Untersuchungen zu den Berührungspunkten beider Literaturwerke (AThAnT 67; Zurich: Theologischer Verlag, 1981); Joel S. Baden, J, E, and the Redaction of the Pentateuch (FAT 68; Tübingen: Mohr Siebeck, 2009), 99-195. Similar efforts have also been made with respect to the laws of Exodus 21-23 and those of Deuteronomy 12-26, notably Bernard M. Levinson, Deuteronomy and the Hermeneutics of Legal Innovation (Oxford: Oxford University Press, 1998). 
What I contend here is that the same sorts of evidence used to reconstruct the literary history of Deuteronomy's relationship with Exodus and Numbers - the existence of parallels, and the nature of those parallels - can also contribute to a final-form reading of Deuteronomy.

On the canonical level (and indeed on any level), the relationship between the stories in Exodus and Numbers and the stories in Deuteronomy is clear: in Exodus and Numbers events happen, and in Deuteronomy those events are remembered. We might put this another way: in Exodus and Numbers, the biblical narrator recounts the events of the past, and in Deuteronomy Moses recounts the events of the past. Or: in Exodus and Numbers, we, the omniscient narrator's audience, are told what happened, and in Deuteronomy the Israelites, Moses's audience, are told what happened. However we describe it, the basic issue remains: there are a handful of events that are narrated twice once in Exodus and Numbers, and again in Deuteronomy.

From the literary-historical perspective, the similarities between the stories in Deuteronomy and those in Exodus and Numbers are what permit us to identify the genetic relationship between the two. The differences, in turn, allow us to identify and describe the perspectives of the respective authors. For a canonical reading, in which these parallel passages are not from independent literary hands but belong to one and the same continuous story, the similarities are entirely sensible; the differences, however, are rather unexpected. Though the parallel renditions of these events may be very similar, indeed even at times word for word, they are never identical. And the differences go beyond mere stylistic change: each parallel story entails at least one significant variation in the recording and rehearsing of the events themselves. Thus a reader can well ask not only what the differences are, but why they are. Specifically: why does Moses, when recounting the events of Israel's recent history, tell a story different from the one that we have already read?

It is perhaps worth noting at this early juncture that the final-form reading I engage with in what follows is not to be set in opposition to the literaryhistorical analysis of the relationship between Deuteronomy and ExodusNumbers. As I have argued repeatedly elsewhere, Deuteronomy (or, more accurately, the D source that constitutes the majority of the book of Deuteronomy) was literarily dependent on the non-priestly sources of Exodus-Numbers. ${ }^{2}$ In a sense, then, the stories in Deuteronomy have always been a response

2 In addition to the reference in the previous footnote, see also "The Deuteronomic Evidence for the Documentary Theory," in The Pentateuch:International Perspectives on Current Research (ed. Thomas B. Dozeman, Konrad Schmid, and Baruch J. Schwartz; FAT 78; Tübingen: Mohr Siebeck, 2011), 327-44. 
to and revision of the parallel stories earlier in the Pentateuch. At the same time, the author of D could surely never have anticipated that his text would come to be placed in material continuity with the very narratives (and laws) that he was revising. For this circumstance we have the compiler or redactor of the Pentateuch to thank. One may thus well believe, as I do, that there is a diachronic, indeed genetic, relationship between Deuteronomy and its textual antecedents, and still recognize that when combined into the canonical Pentateuch a new set of possible readings and meanings is inevitably created. What is to be avoided, however, is the presumption that the final-form reading espoused below, or any such reading, was the deliberate creation of the pentateuchal redactor, as we cannot access the internal machinations of the ancient authors or editors. If it is not possible, then, to speak about the intentions of the redactor, it is possible, and in fact necessary, to inquire into the effects of the redaction. ${ }^{3}$ It is on that level that the final-form reading offered here operates.

In what follows, I will make the case that the differences between Deuteronomy's version of a story and that of Exodus or Numbers follow a set of definable and eventually predictable patterns. Moreover, these differences can, in a final-form reading, be attributed not to divergent authorship, nor to errors of memory, but to the conscious choice of the speaker, Moses, all too aware of his audience within the world of the story.

In this limited space it is not possible to go through every aspect of every parallel story, but we might as well start at the beginning. Moses begins his great speech by bringing his audience back to the mountain in the wilderness, Horeb. ${ }^{4}$ There, he tells them, God instructed the Israelites to depart from the mountain and make their way toward the land that was promised to Abraham, Isaac, and Jacob (Deut 1:6-8). As soon as God had finished speaking, Moses recalls, he turned to the Israelites and began castigating them: "I cannot bear the burden of you by myself!" (1:9). ${ }^{5}$ Because God had multiplied the people, so that they are as numerous as the stars in the sky (1:10), Moses could no longer handle alone the task of governing them: "How can I bear unaided the trouble of you, and the burden, and the bickering!" (1:12). For the attentive reader, these words are familiar: we have heard them from Moses before - or at least something very close to them. In Numbers 11, just after the Israelites have left the

3 On this distinction, and its exegetical ramifications, see my The Promise to the Patriarchs (Oxford: Oxford University Press, 2013), 127-57.

4 Though in a canonical reading Horeb and Sinai are two names for the same mountain, because Deuteronomy uses only the name Horeb to refer to the mountain of the wilderness theophany, I do the same here.

5 Here and throughout translations are based on the NJPS. 
mountain in the wilderness to begin their journey toward Canaan, Moses said, "I cannot bear the burden of this entire people by myself - it is too heavy for me!" (Num 11:14). ${ }^{6}$

The main difference between these two complaints is the variation between "the burden of you" (Deut 1:12) and "the burden of this people" (Num 11:14). It seems minor; but it is an important difference, because it highlights the fact that, in the two tellings of this story, Moses complains in two different directions. In the narrative of Numbers, Moses takes his case directly to God - he even says, "If you would thus deal with me, kill me rather, I beg you" (Num 11:15). But when Moses recalls this event, when he reminds the Israelites of what happened back at the departure from Horeb, he changes the story a little. Now, in Deuteronomy, Moses says that he complained not to God, but to the people. What comes across in Numbers as, frankly, whining is transformed in Deuteronomy into scolding. ${ }^{7}$

Continuing on in Deuteronomy, Moses now tells the people how he decided to ameliorate his situation: "Pick from each of your tribes men who are wise, discerning, and experienced, and I will appoint them as your heads" (Deut 1:13). And the people, according to Moses, replied, "What you propose to do is good" (1:14), and Moses proceeded to appoint officers over the people, at various degrees of hierarchy: chiefs of thousands, chiefs of hundreds, chiefs of fifties, chiefs of tens, and officials for the tribes (1:15). These officers were, Moses says, to act as judges, to "decide justly between any man and a fellow Israelite or stranger" (1:16); and "any matter that is too difficult for you, you shall bring to me and I will hear it" (1:17). Thus, according to Deuteronomy, Moses solved the problem of the people's excessive numbers and the immense burden that he had to bear on their behalf. Two items immediately strike our attention. First: this is not, in fact, the solution that we heard about back in Numbers 11. There, when Moses complained - to God - about his burden, the solution was to bring seventy elders to the Tent of Meeting and to imbue them with some of Moses's prophetic capacity (Num 11:16-17). In Deuteronomy, Moses does not mention the seventy elders. He does not mention the Tent of Meeting, or the spirit of prophecy, or the two elders who remained in the camp, Eldad and Medad. In fact, none of the solution that was reached in Numbers 11 is mentioned by Moses when he recalls that moment in Deuteronomy.

That brings us to the second noteworthy feature of this passage in Deuteronomy: the appointing of hierarchically ordered tribal heads to serve as an

6 On the narrative in Numbers 11, see Benjamin Sommer, "Reflecting on Moses: The Redaction of Numbers 11," JBL 118 (1999): 601-24.

7 See Gerhard von Rad, Deuteronomy (oтL; Philadelphia: Westminster, 1966), 40: "In Num 11 Moses' complaint is directed to Yahweh. It actually borders on blasphemy in its vehemence. But here it is addressed to the people, and by this means it is toned down." 
Israelite judiciary is also well known to us - but not from Numbers 11, or anywhere close to it. We know about these judges from the story in Exodus 18, where we have nearly word-for-word parallels. "Moses chose capable men out of all Israel, and appointed them heads over the people - chiefs of thousands, hundreds, fifties, and tens; and they judged the people at all times: the difficult matters they would bring to Moses, and all the minor matters they would decide themselves" (Exod 18:25//Deut 1:15). Speaking to the Israelites in Deuteronomy, Moses has, it seems, taken the judicial appointments from Exodus 18 and relocated them to the story of Numbers $11 .{ }^{8}$ In the process, he has also seemingly neglected to mention the fact that the idea of appointing judges back in Exodus 18 was not really his idea at all: what has happened to poor Jethro? Moses has taken all the credit for Jethro's one contribution to Israelite culture, and removed his father-in-law from the narrative altogether: Jethro is never mentioned in Deuteronomy.

Yet the more significant issue, surely, is the chronological one: in Deuteronomy, Moses takes an event that happened before the revelation at Horeb and has moved it, quite brazenly, to a moment after the revelation at Horeb. There is no denying, of course, that the two stories have much in common: Moses's struggle to handle by himself the pressures of leading the Israelite community, and the selection of leaders from among the people to take up part of the burden. But we can hardly pretend that they are the same story, or that they are somehow interchangeable - they are not the same story in Exodus and Numbers, after all, and they are not interchangeable, but rather complementary: civil leadership in Exodus 18, religious leadership in Numbers 11. ${ }^{9}$ So what has Moses done here in Deuteronomy, combining them into a single event? On

8 For critical views on the relationship of Deut 1:9-18 and Exodus 18/Numbers 11, see Rose, Deuteronomist und Jahwist, 224-63; William Johnstone, Chronicles and Exodus: An Analogy and its Application (Jsотs 275; Sheffield: Sheffield Academic, 1998), 253-55; Erhard Blum, Studien zur Komposition des Pentateuch (BZAW 189; Berlin: Walter de Gruyter, 199o), 15658; Thomas Römer, "Nombres 11-12 et la question d'une rédaction deutéronomique dans le Pentateuque," in Deuteronomy and Deuteronomic Literature (ed. Marc Vervenne and Johan Lust; BETL 133; Leuven: University Press, 1997), 481-50o (at 489); Erik Aurelius, Der Fürbitter Israels: Eine Studie zum Mosebild im Alten Testament (ConBOT 27; Stockholm: Almqvist \& Wicksell International, 1988), 176-81; Hans Heinrich Schmid, Der sogenannte Jahwist: Beobachtungen und Fragen zur Pentateuchforschung (Zurich: Theologischer Verlag, 1976), 70-75. All of the aforementioned scholars take the material in Exodus and Numbers to be dependent on that of Deuteronomy. The opposite view, that Deuteronomy is taking up earlier material from Exodus and Numbers, was common for much of classical pentateuchal scholarship, and can be found more recently in Joel S. Baden, "The Deuteronomic Evidence for the Documentary Theory," in The Pentateuch: International Perspectives (ed. Thomas B. Dozeman, Konrad Schmid, and Baruch J. Schwartz; FAT 78; Tübingen: Mohr Siebeck, 2011), 327-44 (at 328-36).

9 This despite the efforts of numerous commentators to equate the two. See, e.g., Jack R. Lundbom, Deuteronomy: A Commentary (Grand Rapids: Eerdmans, 2013), 172; Hanoch 
one side, he has cut out Jethro, as already noted. On the other, he has cut out the seventy elders endowed with the prophetic spirit.

All of the aforementioned issues can be placed under a single heading: "Moses makes himself look good."10 First we have the transformation of Moses's whining to God into Moses's scolding of the people. "I wasn't whining," Moses seems to be saying; "You all are the ones who can't stop bickering, not me." Second, we have the removal of Jethro from the narrative. Now the organization of the Israelite judiciary is not a foreigner's idea, it is Moses's." (We also lose Jethro's statement that what Moses is doing, judging all the Israelites by himself, is "not right" [Exod 18:17]). These two differences combine to turn Moses from someone who requires others (God or Jethro) to solve his problems into a strong leader who identifies a problem and proposes a solution - a solution, it should be noted, that in Deuteronomy is acclaimed by the people "You answered me and said, 'What you propose to do is good!" (Deut 1:14) - whereas there is no such popular acclaim in either Exodus 18 or Numbers 11. Moses has not only improved his own position, he has implicated the people in affirming it. And, third, we have the elimination of the seventy elders who share Moses's prophetic spirit. As far as Moses seems to be concerned, there is only one prophetically gifted leader among the Israelites: Moses. This is in line with the rest of Deuteronomy, where Moses speaks not of those prophets who stand alongside him, but those who will come after him, those who are like $\operatorname{him}(18: 15-22) \cdot{ }^{12}$

In short: the retelling in this first episode of Deuteronomy of events that were narrated in Exodus and Numbers differs in ways that can be described as self-aggrandizing on the part of Moses, the speaker of Deuteronomy. It is a pattern that continues elsewhere.

The next story that Moses recounts in Deuteronomy - still in the first chapter - is that of the spies, which we know from Numbers $13-14 .{ }^{13}$ It begins with

Reviv, "The Traditions Concerning the Inception of the Legal System in Israel: Significance and Dating," ZAW 94 (1982): 566-75.

10 The more positive portrayal of Moses in Deuteronomy has been noted by others, including Harvey, Retelling, 14.

11 This is often explained on ideological grounds; see, e.g., Moshe Weinfeld, Deuteronomy 1-11 (AB 5; New York: Doubleday, 1991), 140: "The omission of Jethro's role in the proposal may be motivated by the nationalistic attitude of the book of Deuteronomy."

On the status of Moses as prophet in Deuteronomy and elsewhere in the Pentateuch, see Jeffrey Stackert, A Prophet Like Moses: Prophecy, Law, and Israelite Religion (Oxford: Oxford University Press, 2014).

13 On the relationship of these passages in Deuteronomy and Numbers, see, among others, Ludwig Schmidt, "Die Kundschaftererzählung in Num 13-14 und Dtn 1,19-46: Eine Kritik neuerer Pentateuchkritik," ZAW 114 (2002): 40-58. 
Moses recalling how he told the Israelites to go ahead and take possession of the land (Deut 1:20-21) - which never actually happened, according to Numbers. He then declares that the idea for spying out the land was raised by the Israelites themselves: "Then all of you came to me and said, 'Let us send men ahead to reconnoiter the land for us"' (1:22). This is certainly not what happened in Numbers, though it is not entirely clear whose plan is being usurped by the people in Moses's retelling: it could be Moses's from Numbers 13:17, where he instructs the spies to go up into the hill country; it could be God's, from Numbers 13:2, where he tells Moses to send one man from each tribe. ${ }^{14}$ Either way, Moses is clearly shifting the initiative for the disastrous spies episode onto the people.

When, according to Moses in Deuteronomy, the spies returned to the Israelite camp and gave their report, the people were dismayed by the prospect of facing the fortified cities and giant men who inhabit the land (Deut 1:26-28), as they were in Numbers as well (Num 14:1-4). The Israelites, in both stories, are then duly castigated for their lack of faith. But in Deuteronomy, it is Moses who does the castigating: "I said to you, 'Have no fear of them. None other than the Lord your God who goes before you will fight for you.... You have no faith in the Lord your God'" (Deut 1:29-33). This is not too far off from the speech we find in Numbers 13: "Let us by all means go up, and we shall gain possession of it, for we shall surely overcome it" (Num 13:30); or the similar speech in Numbers 14: "If the Lord is pleased with us, he will bring us into that land.... Have no fear of the people of the country, for they are our prey; their protection has departed from them, but the Lord is with us" (Num 14:8-9). The problem is that in Numbers 13 and 14, it is not Moses who gives either of those speeches, despite what he tells his audience in Deuteronomy. It is, rather, Caleb and Joshua, the two spies who remain loyal to God, the two members of that generation who are promised to survive the forty years of wandering and enter the promised land a reward that, of course, even Moses does not receive.

One might speculate that Moses is perhaps jealous of Caleb and Joshua, and that thus he eliminates them and their heroic role from the story. Yet in the world of the story, Moses well knows that Caleb and Joshua will enter the promised land, because, simply enough, here Moses and the Israelites are standing on the border in Moab, and Caleb and Joshua, alone of the first

14 The two plans in Numbers 13 for sending the spies are due, in source-critical scholarship, to the presence of two intertwined $\mathrm{P}$ and non-P narratives in this section; see, e.g., George B. Gray, A Critical and Exegetical Commentary on Numbers (ICC; Edinburgh: T\&T Clark, 1903), 128-67; Baruch A. Levine, Numbers 1-20 (AB 4; New York: Doubleday 1993), 347-81; Richard E. Friedman, The Bible with Sources Revealed (San Francisco: HarperSanFrancisco, 2003), 262-66. 
generation, are presumably standing there too. So Moses goes on to say that God permitted Caleb to survive (Deut 1:36) - but, confoundingly, he has removed from his version of the story any rationale for Caleb to be an exception. ${ }^{15}$ We can almost see him struggling, on one hand, to take their glory for himself and, on the other, to admit that others have been rewarded.

This sense of internal conflict is borne out by what Moses says next: "Because of you, the Lord was incensed with me too, and he said, 'You shall not enter it either"' (Deut 1:37). While Moses is talking about that lucky fellow who does in fact get to enter the promised land, Caleb, he cannot help but be reminded that he himself will not enter. But, again, he has altered the events narrated in Numbers to flatter himself. Why can Moses not enter the promised land? He blames the Israelites: their disobedience in the episode of the spies rubbed off on him, and he was punished for their sin - "Because of you!" But we who have read the Pentateuch to this point know that this is not really the reason why Moses cannot enter Canaan. We remember the story of Moses getting water from a rock in Numbers 20, the moment when both Moses and Aaron were condemned to die before crossing the Jordan (Num 20:12). Though we may not fully understand that story or what precisely Moses and Aaron did that was so wrong, we at least know that that was the moment when they were prohibited from entering the promised land. ${ }^{16}$ Again, and quite blatantly here, Moses has indisputably changed the story to make himself look better.

This is not a one-off moment for Moses, either: a bit later on, in Deuteronomy 3, Moses tells his audience that when they had arrived in Moab, he had pleaded with God to let him cross the Jordan (Deut 3:23-25), but was rebuffed: "But the Lord was wrathful with me on your account and would not listen to me" (3:26). And then again, in Deuteronomy 4: "The Lord was angry with me on your account and swore that I should not cross the Jordan and enter the good land that the Lord your God is assigning you as a heritage" (4:21). "On your account" - again a total denial of any responsibility for not being allowed into Canaan. In other words, Moses, in Deuteronomy, is consistent both in his

15 That Moses mentions only Caleb in the Deuteronomy account, while the canonical text of Numbers 13-14 clearly designates both Caleb and Joshua as those who will survive the wilderness, is difficult to explain in a final-form context; we might suggest that Joshua's survival is assumed by virtue of his being Moses's designated successor, as was established canonically already in Numbers $27: 15^{-23}$. The solution to this ostensible problem is relatively straightforward when treated source-critically, as the strand of the spies story that Deuteronomy seems most familiar with is the non-P narrative, which does not refer to Joshua at all. See, e.g., S.R. Driver, A Critical and Exegetical Commentary on Deuteronomy (3rd ed.; ICC; Edinburgh: T\&T Clark, 1902), 26.

16 On the obscure interpretation of this episode, see Jacob Milgrom, The JPS Torah Commentary: Numbers (Philadelphia: Jewish Publication Society, 199o), 448-56. 
refusal to take responsibility for his actions and in his general self-aggrandizement.

He is also consistent in his attitude toward the people: when he shifts the blame off of himself, he shifts it onto the Israelite community. Clearly it is not as if the Israelites would be blameless otherwise - great swaths of Exodus and Numbers are little other than the Israelites doing wrong and being punished for it. But as is evident in regard to his inability to enter Canaan, Moses assigns blame even for things for which the Israelites were not really responsible. This is in keeping with the main message that Moses is interested in conveying throughout Deuteronomy: that the people are incorrigible, and intransigent, and generally impossible. ${ }^{17}$ It is Moses, after all, who says to the Israelites at the end of the book, in Deuteronomy 31, "Well I know how defiant and stiffnecked you are; even now, while I am in your midst, you have been defiant toward the Lord; how much more, then, when I am dead!... I know that, when I am dead, you will act wickedly and turn away from the path that I enjoined upon you" (Deut 31:27, 29). This is the central theme of Deuteronomy, the core of Moses's communication to the Israelites: you cannot help yourselves, you are disobedient by nature, and if you could not control yourselves even when I was here to lead you - and note the self-esteem required to say something like that - then you will have no chance at all when I am gone. ${ }^{18}$

Recognizing this as the fundamental attitude of Deuteronomy goes some way toward explaining why Moses tells the stories the way he does - indeed, it helps to explain why Moses is recounting the events of the past at the beginning of Deuteronomy in the first place. When the laws are the novelty, the central reason for Moses to be making this speech in the first place, what is the point of this lengthy historical recollection? ${ }^{19}$ The point is to remind the Israelites how intransigent they have been, and therefore how great the contrast will have to be if they are to try and reform their ways and obey these laws. To that end, every episode that Moses recounts in the introductory chapters of

17 See Richard D. Nelson, Deuteronomy: A Commentary (otL; Louisville: Westminster John Knox, 2002), 56: "That even Moses must endure punishment emphasizes the seriousness of the people's past disobedience."

18 Note that this is not merely Moses's own position, but that of God as well, as is evident from God's speech to Moses in Deut 31:16-21 and the song that follows in Deuteronomy 32:1-47.

19 This question is similar to that asked by the classical rabbis about the Torah as a whole: why does it begin with creation, rather than with the first laws, which they understood to come only in Exodus 12 (see the commentary of Rashi on Gen 1:1). It is even more acute here, however, when the entire history has already been laid out in Genesis-Numbers: the question is not why is history necessary as a preface to law, but why is it necessary to repeat the history before giving further laws? 
Deuteronomy is an episode that illustrates just how difficult the people are. "It is not for any virtue of yours that the Lord your God is giving you this good land to possess; for you are a stiffnecked people. Remember, never forget, how you provoked the Lord your God to anger in the wilderness: from that day that you left the land of Egypt until you reached this place, you have continued defiant toward the Lord," Moses says in Deut 9:6-7. And in this light Moses's self-aggrandizement makes some sense, too: it allows him to say at the end of the book, "You're never going to have anyone better than me, and you were still disobedient even when I was around." Moses's heightened self-image in the beginning of Deuteronomy can, therefore, be read as a necessary setup for the punchline he delivers at its end.

The last major story that Moses recounts in the introductory chapters of Deuteronomy is that of the theophany at Horeb itself, in chapters 9 and $10 .{ }^{20} \mathrm{In}$ keeping with the general theme of his speech, Moses construes virtually the entire encounter as a disaster. Gone from his telling are the laws of Exodus 2123, what we call the Covenant Code; ${ }^{21}$ perhaps even more to the point, gone from his telling are the moments in Exodus when the people, overwhelmed by devotion to their God, repeatedly affirm, "All that the Lord has said we will do!" (Exod 19:8; 24:3, 7). Such demonstrations of obedience are absent in Deuteronomy. What Moses wants to talk about, rather, is the golden calf. That story is damning enough, even in the Exodus version, that Moses hardly needs to embellish the people's part of it all that much to ensure that they look bad. It is, after all, the paradigmatic moment of Israelite apostasy (though it is, strangely enough, not the moment at which the Israelites are actually punished the worst: that honor goes to the spies episode, with the forty years of wandering and the death of the generation).

In any case, Moses does not miss an opportunity in retelling the golden calf story to emphasize his favorite talking points. We may remember that in Exodus, Moses goes up the mountain for forty days (Exod 24:18), during which the people make the calf (32:1-6); God tells Moses that they've done so (32:7-8) and threatens to destroy them (32:9-10), upon which Moses pleads for them (32:1113); then he goes down the mountain and smashes the tablets and punishes the people (32:15-29); and finally thereafter he goes back up the mountain for another forty days to receive the second set of tablets $(34: 1,28)$. Things are a little different when Moses describes all this in Deuteronomy. In Moses's version, he

20 On the literary relationship of Deuteronomy's versions of these events to those of Exodus, see, e.g. Baden, J, E, and the Redaction of the Pentateuch, 153-72.

21 This absence is due not only to the different focus of Deuteronomy, but to Deuteronomy's fundamentally ambivalent, if not in fact outright negative, view toward the laws of the Covenant Code. See Levinson, Deuteronomy. 
goes up the mountain for forty days, during which the people make the calf (Deut 9:9-11); God tells Moses that they've done so (9:12) and threatens to destroy them (9:13-14) - so far just as in Exodus - but then Moses immediately goes down the mountain and smashes the tablets, without first pleading on behalf of the people (9:15-17).

This reordering of events allows Moses to have a far more dramatic moment: having smashed the tablets, he then returned up the mountain: "I threw myself down before the Lord - eating no bread and drinking no water forty days and forty nights, as before - because of the great wrong you had committed" (9:18). Moses both gives himself a more public intervention on behalf of the people and lays the guilt thickly upon them. And then he adds yet another novelty to the story: "Moreover, the Lord was angry enough with Aaron to have destroyed him; so I also interceded for Aaron at that time" (9:20). That does not happen in Exodus, where the only person who confronts Aaron about his role was, in fact, Moses himself. And it is a fairly weak confrontation, at that: in Exodus, Moses says, "What did this people do to you that you have brought such great sin upon them?" (Exod 32:21). Aaron's famously feeble response is that he simply threw their gold into a fire, and out popped this golden calf (32:22-24). And in Exodus, that is the end of it - Moses evidently accepts this answer, or at least does not think that it requires any further investigation. Yet in Deuteronomy, suddenly, Aaron's continuing position of authority among the Israelites, despite his leading role in their moment of greatest apostasy, is due not to Moses's lax prosecution, but rather to Moses's generous intervention with a deity bent on punishment.

In addition to inventing a desire on God's part to punish Aaron, Moses appears also to exaggerate God's desire to punish the Israelites. In Exodus, God expresses his anger and his desire to destroy the people during Moses's first stay on the mountain; Moses is able to persuade God to relent right there and then, before Moses has even turned to go back down and see the calf for himself (32:9-14). In Exodus, God is quick to anger, but is also relatively easy to assuage. ${ }^{22}$ In Deuteronomy, however, God expresses his anger during Moses's first stay on the mountain and stays angry, unappeased, unpersuaded, while Moses goes back down and smashes the tablets. God's anger is extended - and is extended even further when Moses says that it took him forty days of pleading to get God to relent: "When I lay prostrate before the Lord those forty days and forty nights, because the Lord was determined to destroy you, I prayed to

22 Quite the opposite, therefore, of God's own famous self-description in Exod 34:6-7: "slow to anger." 
the Lord and said, 'O Lord God, do not annihilate your very own people”' (Deut 9:25-26).

What Moses has done here, in his retelling of the story, is perhaps more than meets the eye. He has not only pushed back the moment of divine mercy; he has fundamentally altered the nature of the second forty-day ascent of the mountain. In Exodus, Moses goes up the mountain for two forty-day stints: in both cases for the purpose of receiving the tablets inscribed by the finger of God (Exod 24:12; 34:28). Whatever the logic behind the length of the visit, there is at least consistency in the concept: it takes forty days and nights to produce divinely-inscribed tablets. In Deuteronomy, however, this notion is destroyed: the second forty-day trip up the mountain is not in order to receive new tablets, but to plead for the people. Now it is the pleading that takes forty days that is how terrible the Israelites are. And it is only at the end of being prostrate for forty days and nights that God relents and tells Moses to make new tablets and come back up so that they can get carved (Deut 10:1-2). As Moses explains it in Deuteronomy, it does not take forty days and nights to make divinely-inscribed tablets - that can happen almost instantaneously. What takes forty days is convincing God not to destroy the Israelites - an idea that, again, both highlights how great Moses has been and how terrible the people were.

As a corollary, when the second forty-day visit is no longer about making the tablets, the first forty-day visit logically ceases to be about that too. If we know that God does not require forty days for the second inscribing of the tablets with the Decalogue, then why did it take forty days the first time? It would seem, from the perspective of Deuteronomy, that those first forty days were so that the Israelites would have the opportunity and rationale to commit apostasy. They are almost like a setup, like a sting operation: how long can Moses be absent before the people commit the inevitable sin? And we can see how that concept matches up with Moses's final condemnation: if you sin while I'm around, what will you do when I'm gone? Well, we know, actually: it only took Moses's absence for a month or so before the Israelites lost all capacity to obey even the few laws they had already received at that point.

The overarching point should by now be clear enough. After we have read the stories of Exodus and Numbers, the retold versions of them in Deuteronomy contain enough differences that the attentive reader might well sit up and take notice. But almost every difference, and certainly every significant one, falls into one of two categories: an aggrandizement of Moses's status or an emphasis on the people's intransigence. As I have suggested, these two moves are probably best understood as two sides of the same coin, and the stress given them in the first chapters of Deuteronomy pays off in Moses's thesis statement, which comes only at the end of the book in Deut 31:27. 
The question of why Deuteronomy tells these stories differently from Exodus and Numbers is, in this light, answerable by recourse to the simple observation made at the beginning: in Exodus and Numbers, the omniscient biblical narrator recounts the events of the past, while in Deuteronomy Moses recounts the events of the past. Deuteronomy's version is Moses's version. In other words, while Exodus and Numbers are implicitly objective, Deuteronomy is self-consciously subjective. Moses, it turns out, is an unreliable narrator. Because we know that he is a character in the story, and because we know that he has an agenda in this, the final speech of his life, we should not be surprised that he uses the power of storytelling to control and reshape the memory of the past. Like anyone, he is not telling the story of Israel's time in the wilderness just for the sake of presenting facts. He is making a point, and he is presenting a particular version of the past to do so. We are able to recognize just what Moses is up to because we have the "objective facts" in Exodus and Numbers. But even if we did not already know what had "actually" happened, we should still be reading Moses with a hermeneutic of suspicion: every speaker, including Moses, has an agenda, and reading suspiciously is all about uncovering that agenda, and the ways that it is manifested in the act of speech.

The third-person narratives of the Torah, in Exodus and Numbers, are presented to us, as readers, as trustworthy by definition. But we are at no point expected to take Moses's speech as equally reliable. He is making a speech and, like any good politician, or preacher, he is using his pulpit to convince, to persuade, to promote. The Pentateuch, as a text, may indeed approve of Moses's message - indeed, this is hardly disputable - but that does not mean that every word he says is perfectly true.

Perhaps a more interesting question, or at least an equally interesting one, is not why Moses in Deuteronomy presents an alternative version of the past, but how he can get away with it. Not for us, as readers - we can see what he is up to, and judge him accordingly - but for the Israelites in the story who are standing there listening to him: when they hear their own history presented in an alternative version, would they not realize that Moses is not telling the truth exactly, and would that not undermine his message?

To this, the answer is again relatively simple, and goes back to the other observation made at the beginning: in Exodus and Numbers, we are told what happened, and in Deuteronomy, the Israelites are told what happened. But, crucially, not the Israelites who lived through the experiences that Moses is relating. The Israelites who were there when Moses complained of his burden, when he chose leaders to help with the judiciary, when he sent the spies and when they returned, during the making of the golden calf and its aftermath those Israelites have all died in the intervening forty years. Only Caleb and 
Joshua remain - and they could probably be trusted to keep quiet. Every other person who is listening to Moses recount the events of the wilderness was either too young to know what was going on or wasn't born yet.

In other words, Moses knows his audience. He knows that he can tell the stories however he likes, because no one is alive who can challenge him on the details. Moses is taking advantage of the malleability of memory, especially group memory. He is also playing with the necessary gap between an event and its meaning, between history and story, between a fact and its interpretation. What Moses does in Deuteronomy is give the events of the past their meaning: he imbues neutral events with highly charged significance. These episodes didn't just happen - they were indicative of something bigger. They were part of a pattern. The omniscient biblical narrator does not take it upon himself to describe that meaning, that significance, that pattern; that job is left to Moses. It is Moses who, by means of his retrospective journey through the wilderness, crafts the past into a message for the future. And we, as readers, in turn understand the stories in Exodus and Numbers through the lens that Moses provides for us.

Deuteronomy means "second law," and it is certainly that. But it is also second narrative: Moses is the first interpreter of Israel's past, and Moses provided everyone who followed him, from the ancient world to the present, with a model of how to make meaning from events; how to turn history into story. As readers of the Pentateuch, we are merely following in the footsteps of Deuteronomy, and of Moses, the first reader of the Pentateuch. 